\title{
Water Resources of the Southern Hills Regional Aquifer System, Southeastern Louisiana
}

\section{Introduction}

Information concerning the availability, use, and quality of groundwater in the 10 parishes overlying the Southern Hills regional aquifer system of Louisiana (fig. 1) is critical for water-supply management. The purpose of this fact sheet is to present information that can be used by water managers, residents, and others for stewardship of this vital resource. Information on the availability, past and current use, use trends, and water quality from groundwater sources in these parishes is presented. Previously published reports (see References Cited section) and data stored in the U.S. Geological Survey's National Water Information System (U.S. Geological Survey, 2017) are the primary sources of the information presented here.

\section{Groundwater Withdrawals}

In 2014, about 293 million gallons per day (Mgal/d) (table 1; fig. 2) were withdrawn from groundwater sources in the 10-parish area (West Feliciana, East Baton Rouge, East Feliciana, Livingston, Pointe Coupee, St. Helena, St. Tammany, Tangipahoa, Washington, and West Baton Rouge; figs. 1,2) that overlies the Southern Hills regional aquifer system (Buono, 1983; U.S. Geological Survey, 2016). ${ }^{1}$ Most of the groundwater

${ }^{1}$ Water-withdrawal data are based on estimated or reported site-specific data and aggregated data, which are distributed to sources. For a full description of water-use estimate methodology, see "Data Collection" in Sargent (2011). Tabulation of numbers in text and tables may result in different totals because of rounding; nonrounded numbers are used for calculation of totals. withdrawals come from the regional aquifer system, but in the western part of the study area, the Mississippi River alluvial aquifer is also a major source. Withdrawals for public supply accounted for about 48 percent (140.34 Mgal/d), and industrial use accounted for about 32 percent $(94.34 \mathrm{Mgal} / \mathrm{d})$ of the total withdrawn (table 1). Other categories of use included power generation, rural domestic, livestock, general irrigation, rice irrigation, and aquaculture. Water-use data collected at 5-year intervals from 1960 to 2010 and again in 2014 (fig. 2) indicated that groundwater withdrawals peaked in 2014. These withdrawals were highest in East Baton Rouge Parish (148.26 Mgal/d) and lowest in St. Helena Parish (1.79 Mgal/d) (fig. 1).
Table 1. Groundwater withdrawals, 2014, in million gallons per day, by use category in the 10-parish area overlying the Southern Hills regional aquifer system, Louisiana (U.S. Geological Survey, 2016).

\begin{tabular}{lc}
\hline \multicolumn{1}{c}{ Use category } & Groundwater \\
\hline Public supply & 140.34 \\
Industrial & 94.34 \\
Power generation & 9.69 \\
General irrigation & 23.18 \\
Rice irrigation & 3.47 \\
Rural domestic & 12.83 \\
Livestock & 0.57 \\
Aquaculture & 8.23 \\
Total & $\mathbf{2 9 2 . 6 5}$ \\
\hline
\end{tabular}

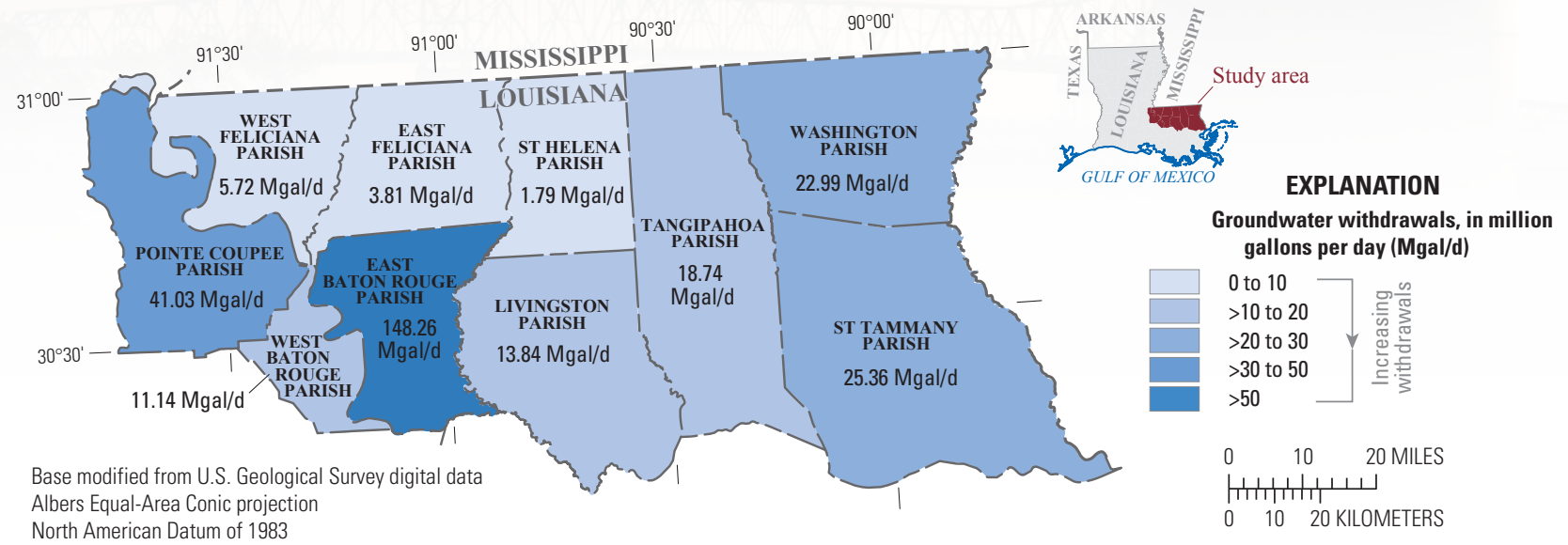

Figure 1. Location of the 10-parish area overlying the Southern Hills regional aquifer system with 2014 groundwater withdrawals, Louisiana. Darker shading indicates greater withdrawal amount (U.S. Geological Survey, 2016). 


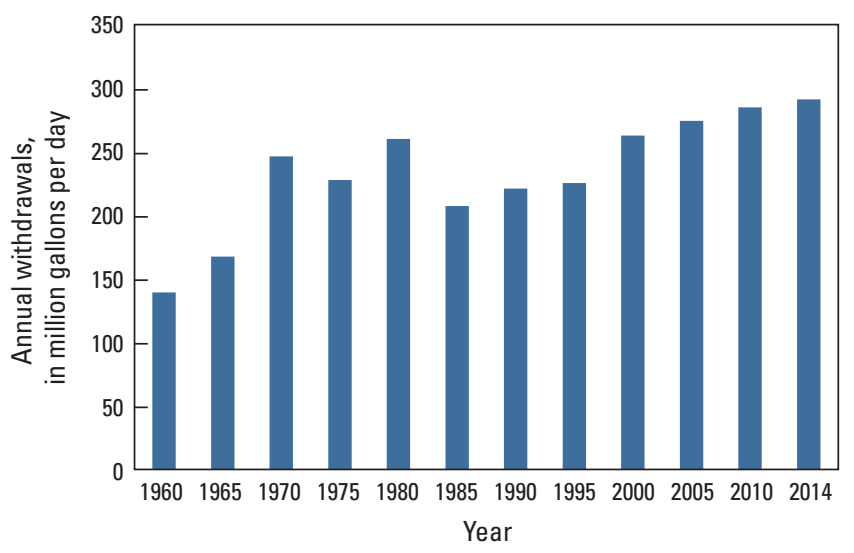

Figure 2. Groundwater withdrawals in the 10 parishes overlying the Southern Hills regional aquifer system in Louisiana, 1960-2014 (U.S. Geological Survey, 2016).

\section{Groundwater Resources}

Fresh groundwater (water with a chloride concentration of 250 milligrams per liter $[\mathrm{mg} / \mathrm{L}]$ or less) in the Southern Hills regional aquifer system in Louisiana is present in three aquifer systems: from shallowest to deepest, (1) the Chicot equivalent, (2) Evangeline equivalent, and (3) Jasper equivalent aquifer systems (figs. 3, 4). The Mississippi River alluvial aquifer is present along much of the western edge of East Baton Rouge and West Feliciana Parishes and within Pointe Coupee and West Baton Rouge Parishes. The Mississippi River alluvial aquifer is hydraulically connected to the Chicot equivalent aquifer system in localized areas but is not considered part of the Southern Hills regional aquifer system.

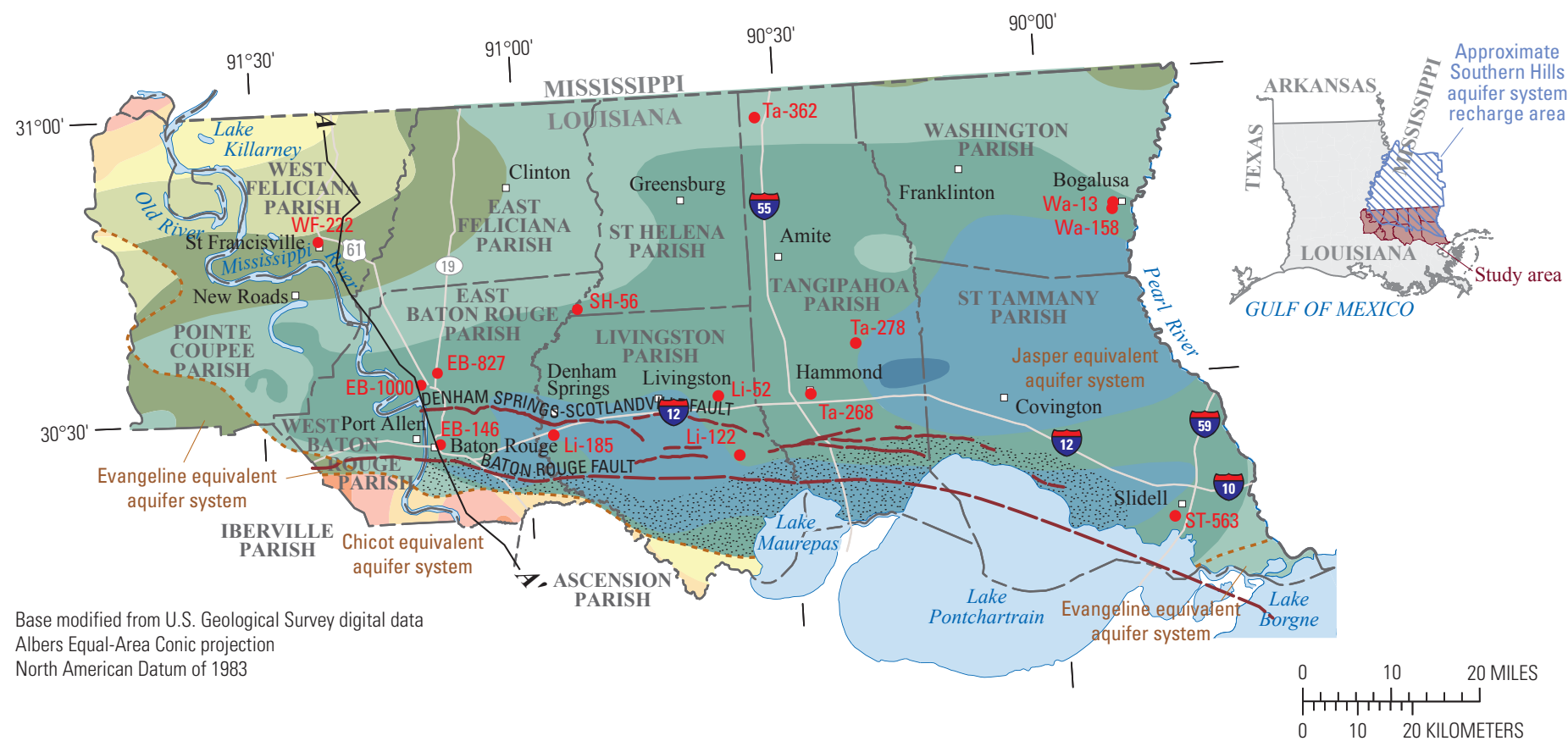

EXPLANATION

\begin{tabular}{|c|c|}
\hline \multicolumn{2}{|c|}{$\begin{array}{l}\text { Approximate altitude of base of fresh groundwater, in feet below the National } \\
\text { Geodetic Vertical Datum of } 1929 \text { (NGVD 29)(modified from Smoot, 1988)- } \\
\text { Deepest freshwater contained within the Jasper equivalent aquifer system, } \\
\text { except where noted }\end{array}$} \\
\hline 0 to 299 & 1,500 to 1,999 \\
\hline 300 to 499 & 2,000 to 2,499 \\
\hline 500 to 699 & 2,500 to 2,999 \\
\hline 700 to 999 & 3,000 to 3,499 \\
\hline 1,000 to 1,499 & 3,500 and deeper \\
\hline
\end{tabular}

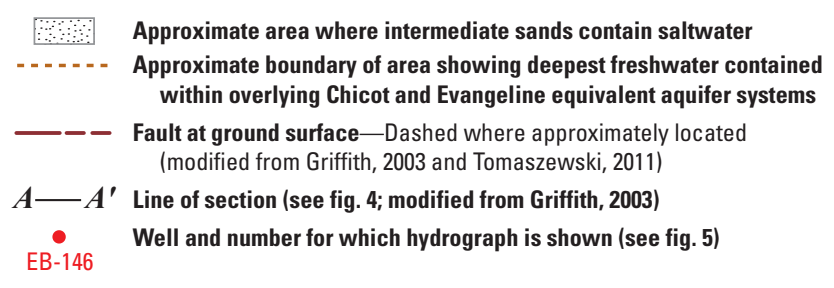

Figure 3. Hydrogeologic features of the Southern Hills regional aquifer system in the study area with section line and well locations (see fig. 4 for cross-section and fig. 5 for well hydrographs).

The Chicot, Evangeline, and Jasper equivalent aquifer systems extend across most of southeastern Louisiana and generally consist of silt, sand, and gravel separated by discontinuous layers of clay and sandy clay. The aquifer systems dip and thicken to the south and contain freshwater to depths of greater than 3,500 feet (ft) below the
National Geodetic Vertical Datum of 1929 (NGVD 29) (fig. 3). Recharge to the aquifers is primarily by precipitation in outcrop areas across the northern part of the 10-parish area and in southwestern Mississippi (Griffith, 2003) (figs. 3, 4).

Prior to development of the regional aquifer system, which began in the late 1800s (Harris, 1904), groundwater generally flowed from north to south and towards the Mississippi and Pearl Rivers (Kuniansky, 1989; Martin and Whiteman, 1989; Halford and Lovelace, 1994).

Development of the aquifer systems has altered the direction of flow in some areas, particularly near Baton Rouge, where large regional cones of depression have formed in the water-level surfaces 


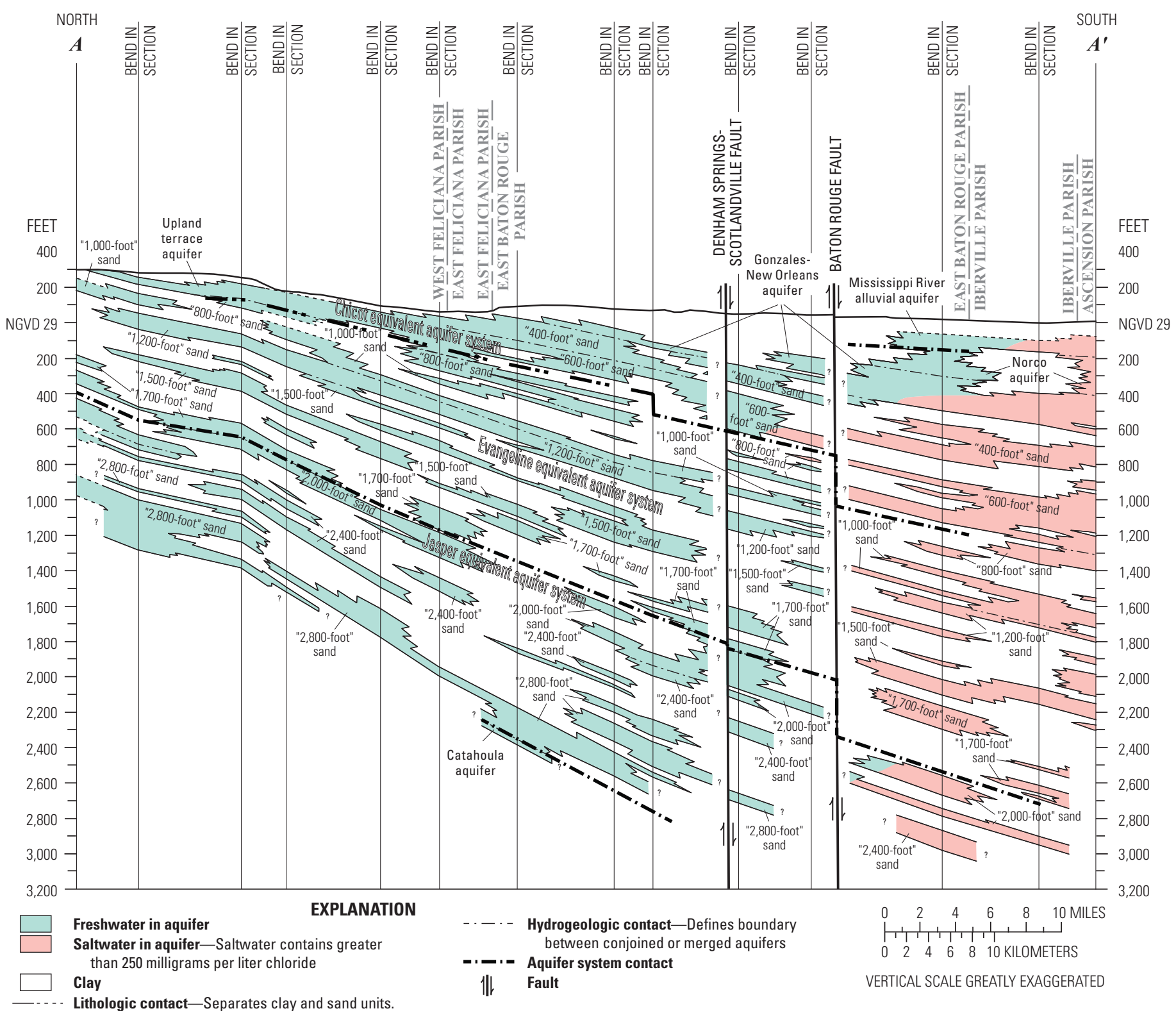

Dashed where approximate. Queried where uncertain

Figure 4. Generalized north-to-south hydrogeologic section through the western part of the Southern Hills regional aquifer system, Louisiana (modified from Griffith, 2003). Trace of section shown on figure 1.

in wells screened in these aquifer systems. A smaller local cone of depression has been observed near Bogalusa in the Jasper equivalent aquifer system. Cones of depression indicate that groundwater is moving radially towards the center of the cone (Prakken, 2004; Fendick, 2007; Tomaszewski, 2011).

Generally, the location of the Baton Rouge Fault (fig. 3) coincides with abrupt changes in availability of freshwater (fig. 4). North of the fault, the base of fresh groundwater is consistently present in the Jasper equivalent aquifer system, in some places to deeper than $3,500 \mathrm{ft}$ below NGVD 29. In general, south of the fault, the depth of the base of fresh groundwater transitions and is restricted to the Chicot equivalent aquifer system; however, freshwater extends south of the fault to a limited distance in the Evangeline and Jasper equivalent aquifer systems in some areas. Salty groundwater movement in East Baton Rouge Parish affects the availability of fresh groundwater. Large groundwater withdrawals in the Baton Rouge area have induced northward encroachment of saltwater across the Baton Rouge Fault into freshwater areas in some locations (Griffith, 2003).

Water levels and withdrawals vary by aquifer system. Water levels remained stable in wells screened in the upper part of the Chicot equivalent aquifer system during 2002-11 (fig. 5A), whereas wells screened in the lower part of the Chicot equivalent aquifer system declined in the western parts of the 10-parish area during 1991-2012 (fig. 5B). Water levels have generally declined during the last 20-60 years at monitored wells screened in the Evangeline and Jasper equivalent aquifer systems because of withdrawals (figs. $5 C, D$ ). Declines have generally been the greatest near withdrawal centers in and near the Baton Rouge metropolitan area. In 2014, withdrawals increased with aquifer-system depth: Chicot equivalent (40.99 Mgal/d), Evangeline equivalent (100.35 Mgal/d), and Jasper equivalent (118.8 Mgal/d). 
A. Upper Chicot equivalent aquifer system

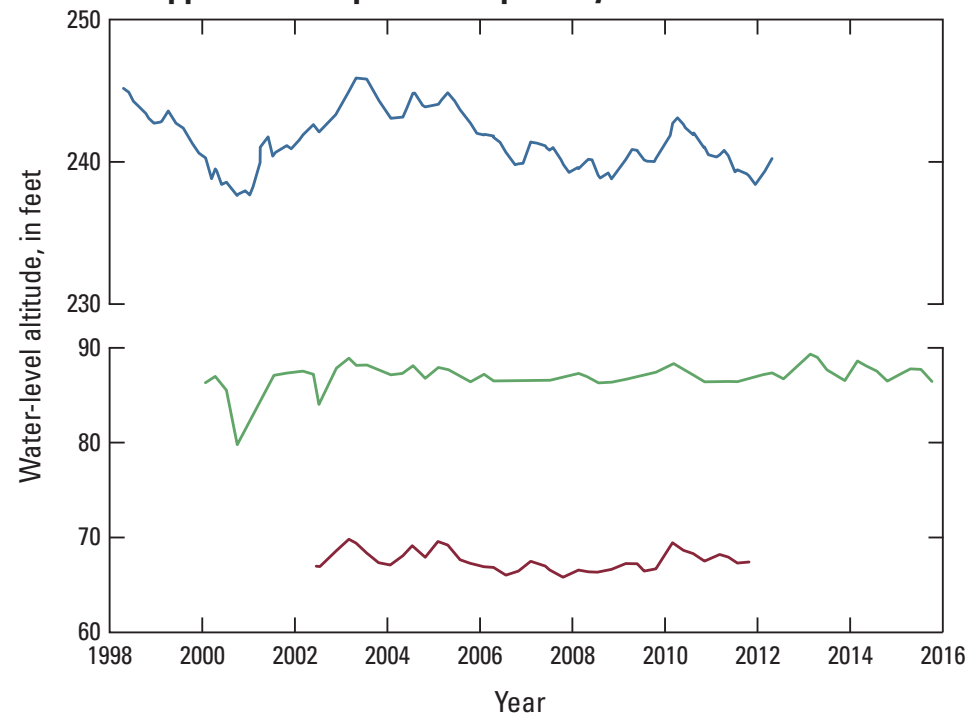

EXPLANATION

Well: Ta-362 Aquifer: Upland terrace Well depth: $43 \mathrm{ft}$ below land surface

Well: SH-56 Aquifer: Upland terrace Altitude of land surface: $77 \mathrm{ft}$ above NGVD 29 Well depth: $160 \mathrm{ft}$ below land surface

Well: Wa-13 Aquifer: Upland terrace

Altitude of land surface: $95 \mathrm{ft}$ above NGVD 29

Well depth: $156 \mathrm{ft}$ below land surface

\section{Evangeline equivalent aquifer system}

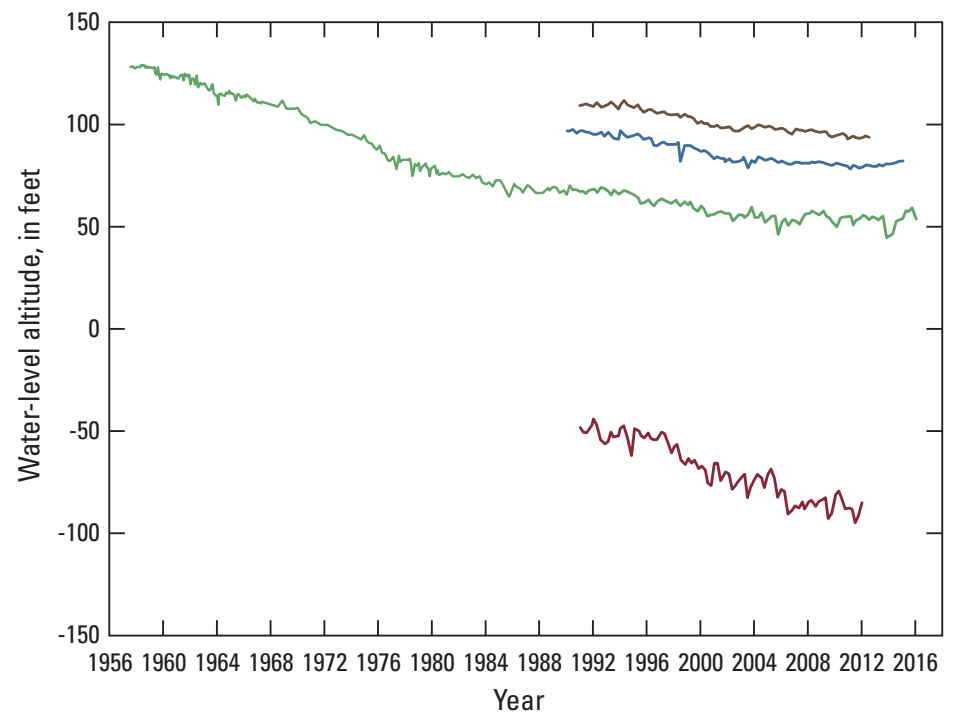

EXPLANATION

Well: Ta-278 Aquifer: Covington

Altitude of land surface: $52 \mathrm{ft}$ above NGVD 29

Well depth: 1,430 ft below land surface

Well: Li-52 Aquifer: "1,700-foot" sand of the Baton Rouge area

Altitude of land surface: $46 \mathrm{ft}$ above NGVD 29

Well depth: 1,865 ft below land surface

Well: ST-563 Aquifer: Slidell aquifer

Altitude of land surface: $10 \mathrm{ft}$ above NGVD 29

Well depth: 2,411 feet below land surface

Well: EB-146 Aquifer: "1,200-foot" sand of the Baton Rouge area

Altitude of land surface: $52 \mathrm{ft}$ above NGVD 29

Well depth: 1,259 ft below land surface

\section{B. Lower Chicot equivalent aquifer system}

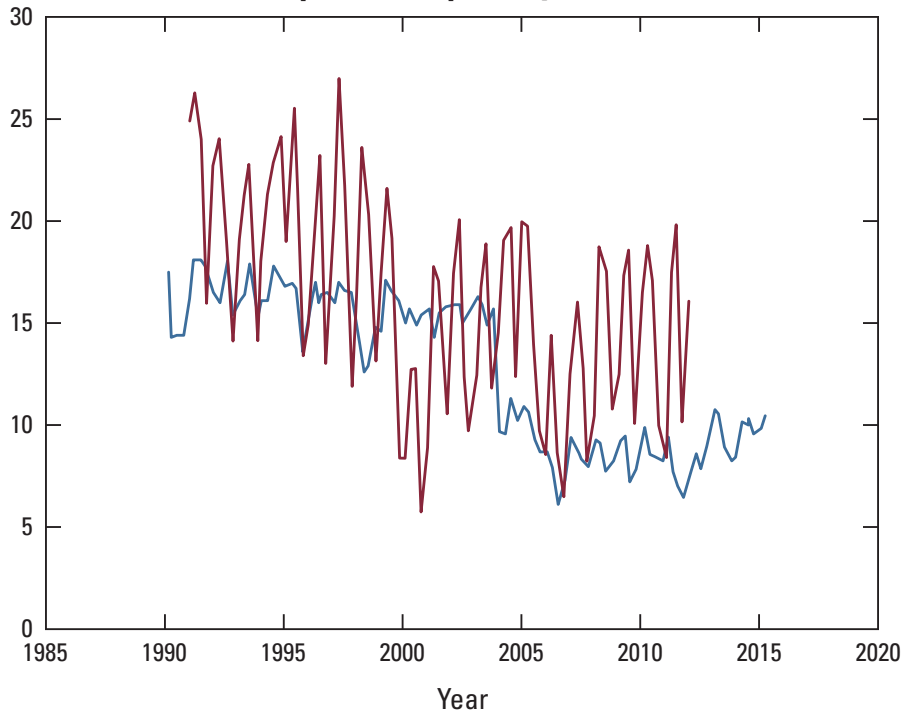

EXPLANATION

Well: EB-827 Aquifer: "600-foot" sand of the Baton Rouge area Altitude of land surface: $64 \mathrm{ft}$ above NGVD 29 Well depth: $370 \mathrm{ft}$ below land surface

Well: Li-122 Aquifer: "400-foot" sand of the Baton Rouge area Altitude of land surface: $11 \mathrm{ft}$ above NGVD 29

Well depth: $500 \mathrm{ft}$ below land surface

\section{Jasper equivalent aquifer system}

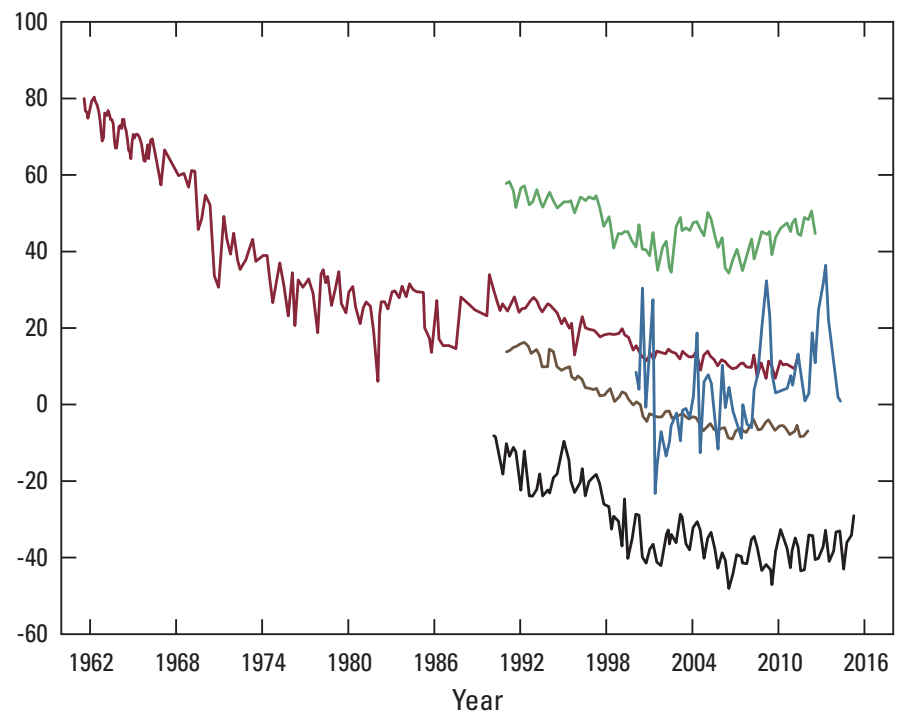

EXPLANATION

Well: Ta-268 Aquifer: Hammond

Altitude of land surface: $35 \mathrm{ft}$ above NGVD 29 Well depth: 2,449 ft below land surface

Well: WF-222 Aquifer: "2,400-foot" sand of the Baton Rouge area Altitude of land surface: $140 \mathrm{ft}$ above NGVD 29

Well depth: 1,526 ft below land surface

Well: Wa-158 Aquifer: Amite

Altitude of land surface: $97 \mathrm{ft}$ above NGVD 29

Well depth: 1,414 ft below land surface

Well: EB-1000 Aquifer: "2,800-foot" sand of the Baton Rouge area Altitude of land surface: $68 \mathrm{ft}$ above NGVD 29

Well depth: 2,926 ft below land surface

Well: Li-185 Aquifer: "2,400-foot" sand of the Baton Rouge area

Altitude of land surface: $37 \mathrm{ft}$ above NGVD 29

Well depth: $2,611 \mathrm{ft}$ below land surface

Figure 5. Water levels in wells screened in the $A$, upper part of the Chicot equivalent aquifer system; $B$, lower part of the Chicot equivalent aquifer system; $C$, Evangeline equivalent aquifer system; and $D$, Jasper equivalent aquifer system of the Southern Hills regional aquifer system, Louisiana (see fig. 3 for well locations; U.S. Geological Survey, 2017). Land surface and water-level altitude are in feet (ft) relative to the National Geodetic Vertical Datum of 1929 (NGVD 29). 
In addition, $31.99 \mathrm{Mgal} / \mathrm{d}$ were withdrawn from the Mississippi River alluvial aquifer in Pointe Coupee (28.05 Mgal/d), West Baton Rouge (3.87 Mgal/d), East Baton Rouge (0.06 Mgal/d), and West Feliciana (0.01 Mgal/d) Parishes (U.S. Geological Survey, 2016).

\section{The Chicot Equivalent Aquifer System}

The primary aquifers composing the Chicot equivalent aquifer system in the western part of the 10-parish area, from shallowest to deepest, are the shallow sands, Upland terrace aquifer, and the "400-foot" and " 600 -foot" sands of the Baton Rouge area (Griffith, 2003; fig. 4). In the eastern part of the 10-parish area, from shallowest to deepest, the primary aquifers are the Upland terrace and upper Ponchatoula aquifers.

In 2016, State well-registration records listed 26,358 active water wells screened in the Chicot equivalent aquifer system in the Southern Hills region, including 23,743 domestic, 1,477 irrigation, 1,006 public supply, and 132 industrial. Well depths ranged from 10 to $980 \mathrm{ft}$ below land surface, and reported yields ranged from 1 to 3,000 gallons per minute (gal/ min) (data provided by Louisiana Department of Natural Resources Office of Conservation /Environmental Division, 2016).

\section{The Evangeline Equivalent Aquifer System}

The primary aquifers composing the Evangeline equivalent aquifer system, from shallowest to deepest, in the western part of the 10-parish area are the "800-foot," "1,000-foot," "1,200-foot," "1,500-foot," and "1,700-foot" sands of the Baton Rouge area (Griffith, 2003; fig. 4). In the eastern part of the 10-parish area, the primary aquifers are the Lower Ponchatoula, Big Branch, Kentwood, Abita, Covington, and Slidell aquifers.

In 2016, State well-registration records listed 2,552 active water wells screened in the Evangeline equivalent aquifer system in the Southern Hills region, including 428 public supply, 91 industrial, 1,870 domestic, 156 irrigation, and 7 power generation. Well depths ranged from 60 to 2,460 ft below land surface, and reported yields ranged from about 1 to 3,000 gal/min (data provided by Louisiana Department of Natural

Resources Office of Conservation/

Environmental Division, 2016).

\section{The Jasper Equivalent Aquifer System}

The primary aquifers composing the Jasper equivalent aquifer system, from shallowest to deepest, in the western part of the 10-parish area are the "2,000-foot," "2,400-foot," and "2,800-foot" sands of the Baton Rouge area (Griffith, 2003; fig. 4). In the eastern part of the 10-parish area, the primary aquifers are the Tchefuncte, Hammond, Amite, Ramsay, and Franklinton aquifers.

In 2016, State well-registration records listed 564 active water wells screened in the Jasper equivalent aquifer system in the Southern Hills region, including 329 public supply, 69 industrial, 130 domestic, 10 power generation, and 26 irrigation. Well depths ranged from 469 to 3,072 ft below land surface. Reported yields from these wells ranged from about 5 to $3,400 \mathrm{gal} / \mathrm{min}$ (data provided by Louisiana Department of Natural Resources Office of Conservation/Environmental Division, 2016).

\section{Water Quality}

Freshwater samples collected from 1,522 wells screened in the Chicot, Evangeline, and Jasper equivalent aquifer systems of the Southern Hills regional aquifer system indicate that groundwater from the aquifer systems is soft ${ }^{2}$ and does not exceed the U.S. Environmental Protection Agency's Secondary Maximum Contaminant Levels (SMCLs) ${ }^{3}$ for dissolved-solids concentrations. Median values for $\mathrm{pH}$ and temperature in groundwater increase as aquifer-system depth increases (table 2). Localized concentrations of iron and manganese can greatly exceed the SMCLs.

${ }^{2}$ Hardness ranges, expressed as milligrams per liter of calcium carbonate, are as follows: 0-60, soft; 61-120, moderately hard; 121-180, hard; greater than 180, very hard (Hem, 1985).

${ }^{3}$ The SMCLs are nonenforceable Federal guidelines regarding cosmetic effects (such as tooth or skin discoloration), aesthetic effects (such as taste, odor, or color), or technical effects (such as damage to water equipment or reduced effectiveness of treatment for other contaminants) of drinking water. SMCLs were established as guidelines by the U.S. Environmental Protection Agency (2016).

\section{References Cited}

Buono, A., 1983, The Southern Hills regional aquifer system of southeastern Louisiana and southwestern Mississippi: U.S. Geological Survey Water-Resources Investigations Report 83-4189, 43 p. [Also available at https://pubs.er.usgs.gov/publication/ wri834189.]

Fendick, R.B., Jr., 2007, Louisiana ground-water map no. 22-Generalized potentiometric surface of the Amite aquifer and "2,800-foot" sand of the Baton Rouge area in southeastern Louisiana, June-August 2006: U.S. Geological Survey Scientific Investigations Map 2984, 1 sheet, accessed March 2, 2012, at http://pubs.usgs.gov/ $\operatorname{sim} / 2984 /$.

Griffith, J.M., 2003, Hydrogeologic framework of southeastern Louisiana: Louisiana Department of Transportation and Development Water Resources Technical Report no. 72, 21 p., 18 pls.

Halford, K.J., and Lovelace, J.K., 1994, Analysis of ground-water flow in the " 1,200 foot" aquifer, Baton Rouge area, Louisiana: Louisiana Department of Transportation and Development Water Resources Technical Report no. 54, 68 p.

Harris, G.D., 1904, Underground waters of southern Louisiana, with discussions of their uses for water supplies and for rice irrigation, by M.L. Fuller: U.S. Geological Survey Water-Supply Paper 101, 98 p.

Hem, J.D., 1985, Study and interpretation of the chemical characteristics of natural water (3d ed.): U.S. Geological Survey Water-Supply Paper 2254, 264 p., accessed February 20, 2013, at http://pubs.er.usgs. gov/publication/wsp2254.

Kuniansky, E.L., 1989, Geohydrology and simulation of ground-water flow in the "400-foot," "600-foot," and adjacent aquifers, Baton Rouge area, Louisiana: Louisiana Department of Transportation and Development Water Resources Technical Report no. 49, 90 p.

Martin, Angel, Jr., and Whiteman, C.D., Jr., 1989, Geohydrology and regional groundwater flow of the coastal lowlands aquifer system in parts of Louisiana, Mississippi, Alabama, and Florida - A preliminary analysis: U.S. Geological Survey WaterResources Investigations Report 88-4100, $88 \mathrm{p}$.

Prakken, L.B., 2004, Louisiana ground-water map no. 17-Generalized potentiometric surface of the Kentwood aquifer system and the "1,500-foot" and "1,700-foot" sands of the Baton Rouge area in southeastern Louisiana, March-April 2003: U.S. Geological Survey Scientific Investigations Map 2862, 2 sheets, accessed February 24, 2012, at http://pubs.er.usgs.gov/publication/ $\operatorname{sim} 2862$. 
Table 2. Summary of selected water-quality characteristics for 1,522 wells screened in the Chicot, Evangeline, and Jasper equivalent aquifer systems in the 10 parishes overlying the Southern Hills regional aquifer system (U.S. Geological Survey, 2017).

[Values are in milligrams per liter, except as noted. ${ }^{\circ} \mathrm{C}$, degree Celsius; $\mathrm{SU}$, standard unit; $\mathrm{CaCO}_{3}$, calcium carbonate; $\mu \mathrm{g} / \mathrm{L}$, microgram per liter; $<$, less than; $\mathrm{SMCL}$, Secondary Maximum Contaminant Level established by the U.S. Environmental Protection Agency (2016); NA, not applicable]

\begin{tabular}{|c|c|c|c|c|c|c|c|}
\hline & $\begin{array}{c}\text { Temperature } \\
\left({ }^{\circ} \mathrm{C}\right)\end{array}$ & $\begin{array}{l}\text { pH, field } \\
\text { (SU) }\end{array}$ & $\begin{array}{l}\text { Hardness } \\
\text { (as } \mathrm{CaCO}_{3} \text { ) }\end{array}$ & $\begin{array}{c}\text { Chloride, } \\
\text { filtered (as CI) }\end{array}$ & $\begin{array}{l}\text { Iron, filtered, } \\
\mu \mathrm{g} / \mathrm{L} \text { (as Fe) }\end{array}$ & $\begin{array}{c}\text { Manganese, } \\
\text { filtered, } \mu \mathrm{g} / \mathrm{L} \\
\text { (as Mn) }\end{array}$ & $\begin{array}{l}\text { Dissolved } \\
\text { solids, filtered }\end{array}$ \\
\hline \multicolumn{8}{|c|}{ Chicot equivalent aquifer system (1939-2015; 476 wells) } \\
\hline Median & 22.5 & 7.1 & 22 & 11 & 100 & 50 & 194 \\
\hline 10th percentile & 20 & 5.2 & 6 & 3.1 & $<4$ & $<0.8$ & 48 \\
\hline 90th percentile & 24.5 & 8.2 & 98.8 & 120 & 1,100 & 311 & 418.8 \\
\hline Number of samples & 625 & 402 & 813 & 1,516 & 197 & 204 & 230 \\
\hline $\begin{array}{l}\text { Percentage of samples that } \\
\text { do not exceed SMCLs }\end{array}$ & NA & 65 & NA & NA & 71 & 50 & 95 \\
\hline \multicolumn{8}{|c|}{ Evangeline equivalent aquifer system (1936-2015; 544 wells) } \\
\hline Median & 28 & 7.9 & 5 & 4.4 & 70 & 20.5 & 198 \\
\hline 10th percentile & 22.5 & 6.5 & 1 & 2.3 & $<10$ & $<10$ & 110 \\
\hline 90th percentile & 32.1 & 8.9 & 25 & 100 & 1,200 & 183 & 260.4 \\
\hline Number of samples & 987 & 546 & 1,165 & 2,005 & 259 & 208 & 397 \\
\hline $\begin{array}{l}\text { Percentage of samples that } \\
\text { do not exceed SMCLs }\end{array}$ & NA & 63 & NA & 100 & 76 & 64 & 99 \\
\hline \multicolumn{8}{|c|}{ Jasper equivalent aquifer system (1939-2014; 502 wells) } \\
\hline Median & 31.2 & 8.3 & 4 & 4.1 & 90 & 20 & 213 \\
\hline 10th percentile & 24 & 7 & 1 & 1.6 & $<10$ & $<5.0$ & 160.8 \\
\hline 90th percentile & 36 & 9 & 20 & 140 & 1,300 & 199 & 391.6 \\
\hline Number of samples & 905 & 647 & 1,101 & 1,893 & 342 & 242 & 459 \\
\hline $\begin{array}{c}\text { Percentage of samples that } \\
\text { do not exceed SMCLs }\end{array}$ & NA & 57 & NA & 100 & 74 & 67 & 95 \\
\hline \multicolumn{8}{|c|}{ SMCLs } \\
\hline & NA & $6.5-8.5$ & NA & 250 & 300 & 50 & 500 \\
\hline
\end{tabular}

Sargent, B.P., 2011, Water use in Louisiana, 2010: Louisiana Department of Transportation and Development Water Resources Special Report no. 17, 135 p.

Smoot, C.W., 1988, Louisiana hydrologic atlas map no. 3-Altitude of the base of freshwater in Louisiana: U.S. Geological Survey Water-Resources Investigations Report 86-4314, 1 sheet, accessed November 2, 2011, at http://pubs.er.usgs. gov/publication/wri864314.

Tomaszewski, D.J., 2011, Water-level surface in the Chicot equivalent aquifer system in southeastern Louisiana, 2009: U.S. Geological Survey Scientific Investigations Map 3173, 2 pls., accessed February 24, 2012, at http://pubs.usgs.gov/sim/3173/.
U.S. Environmental Protection Agency, 2016, Secondary Drinking Water Standards: Guidance for Nuisance Chemicals, accessed April 13, 2016, at https://www.epa.gov/ dwstandardsregulations/secondary-drinkingwater-standards-guidance-nuisancechemicals.

U.S. Geological Survey, 2016, U.S. Geological Survey Water Resources Cooperative Program: Louisiana Water Use Program, accessed October 17, 2016, at http://la.water. usgs.gov/WaterUse/default.asp.

U.S. Geological Survey, 2017, National Water Information System-Web Interface: U.S. Geological Survey Web page, accessed February 1, 2017, at http://dx.doi. org/10.5066/F7P55KJN.
This fact sheet was published by the U.S. Geological Survey in cooperation with the Louisiana Department of Transportation and Development.

\section{By Vincent E. White}

\section{For additional information, contact:}

Director, USGS Lower Mississippi-Gulf Water Science Center 3535 S. Sherwood Forest Blvd., Suite 120 Baton Rouge, LA 70816

E-mail: gs-w-lmg_center_director@usgs.gov Fax: (225) 298-5490

Telephone: (225) 298-5481

Home Page: http://la.water.usgs.gov 